\title{
Derleme
}

Mersin Üniv Sağlık Bilim Derg 2020;13(1):140-154

doi: $10.26559 /$ mersinsbd.624135

\section{Doğal ve yapay tatlandırıcıların glukoz intoleransı, karaciğer enzimleri ve oksidatif stres üzerine etkisi}

\author{
Merve Pehlivan', Eda Köksal ${ }^{2}$ \\ ${ }^{1}$ Kırklareli Üniversitesi Sağlık Yüksekokulu, Beslenme ve Diyetetik Bölümü, Kırklareli, Türkiye \\ ${ }^{2}$ Gazi Üniversitesi, Sağllk Bilimleri Fakültesi Beslenme ve Diyetetik Bölümü, Ankara, Türkiye
}

\section{Özet}

Son zamanlarda düşük enerjili ya da enerjisiz tatlandırıcılar enerji ve glisemik etkilerden uzak oldukları gerekçesi ile şeker ikamesi olarak oldukça sık kullanılmaktadırlar. Bu tatlandırıcı türlerinin saf olarak kullanılması dışında günümüzde gıda ürünlerinin içerisinde sıkça bulunmaları tüketiciler tarafından alımını oldukça artırabilmektedir. Tatlandırıcılar sağlık üzerine etkileri açısından doğal ve yapay tatlandırıcılar olarak ikiye ayrılmaktadır. Deney hayvanlarında yapılan çalışmalarda yapay tatlandırıcı tüketimi enerji dengesini bozarak abdominal obezite, insülin direnci ve/veya bozulmuş glukoz toleransı dahil olmak üzere birçok metabolik sendrom bileșeni ile ilișkilendirilmektedir. Ayrıca karaciğer enzimleri ve oksidatif stres üzerine olumsuz etkisi olduğu da bildirilmektedir. Ancak yapay tatlandırıcıların glukoz intoleransını artırdığı, karaciğer enzimlerini ve oksidatif stres parametrelerini olumsuz etkilediğine dair çalışmaların yanında anlamlı sonuç bulunamayan çalışmalarda mevcuttur. Bunun yanında doğal tatlandırıcıların insülin duyarlılığını artırdığı, kan glukozu üzerinde yararlı etkilerinin olduğu, karaciğer enzimleri ve oksidatif stres parametrelerini azaltıcı bir rol oynadıkları belirli çalışmalarda bildirilmektedir. Fakat doğal tatlandırıcıların bu parametreler üzerinde anlamlı etkisinin olmadığına dair çalıșmalarda mevcuttur. Bu nedenle bu derlemede doğal ve yapay tatlandırıcıların glukoz intoleransı, karaciğer enzimleri ve oksidatif stres üzerine olan etkilerine yönelik çalışmaların derlenmesi amaçlanmıştır.

Anahtar kelimeler: Tatlandırıcılar, glukoz intoleransı, karaciğer enzimleri, oksidatif stres

Sorumlu Yazar: Dr. Öğr. Üyesi Merve Pehlivan, Kırklareli Üniversitesi, SYO, Beslenme ve Diyetetik Bölümü, Cumhuriyet Mahallesi Kofcaz Yolu Kayalı Yerleșkesi Merkezi Derslikler 2 No:39/L Merkez/Kırklareli, Türkiye 


\title{
Effects of natural and artificial sweeteners on glucose intolerance, liver enzymes and oxidative stress
}

\begin{abstract}
Recently, low-energy or non-energy sweeteners have been used frequently as sugar substitutes on the ground that they are free from energy and glycemic effects. Moreover, apart from use of these sweetener types in pure form, the fact that they are included in products today increases the intake of them by consumers considerably. Sweeteners are classified as natural and artificial sweeteners in terms of their health effects. In studies conducted on experimental animals, artificial sweetener consumption is associated with many metabolic syndrome components, including abdominal obesity, insulin resistance and/or impaired glucose tolerance through disrupting energy balance. In addition, adverse effects on liver enzymes and oxidative stress have been reported. However, studies have shown that artificial sweeteners increase glucose intolerance, negatively affect liver enzymes and oxidative stress parameters, as well as studies that have found no significant results. Besides, certain studies have reported that natural sweeteners increase insulin sensitivity, have beneficial effects on blood glucose, and reduce liver enzymes and oxidative stress parameters. However, some studies have shown that natural sweeteners have no significant effect on these parameters. Therefore, it is aimed to review the effects of natural and artificial sweeteners on glucose intolerance, liver enzymes and oxidative stress in this review article.
\end{abstract}

Keywords: Sweeteners, glucose intolerance, liver enzymes, oxidative stress

\section{Giriş}

Düşük enerjili ya da enerjisiz tatlandırıcılar enerjiden veya glisemik etkilerden arındırılmış bir tat sundukları için şekerin sağlıklı alternatifleri olarak düşünülmektedirler ${ }^{1}$ ve 19 . yüzyılın sonundan bu yana kullanılmaktadırlar. ${ }^{2}$ Günümüzde, altı yapay düşük enerjili ya da enerjisiz tatlandırıcı (sakkarin, aspartam, asesülfam potasyum, sukraloz, neotamin ve advantam) gidalarda tatlandırıcı olarak kullanılmak üzere Amerikan Gıda ve İlaç İdaresi (FDA) tarafından onaylanmıştır. İki doğal düşük enerjili ya da enerjisiz tatlandırıcı (steviol glukozitler ve Luo han guo özü) ise genel olarak güvenli olarak kabul edilip, FDA tarafından gıdalarda kullanılmalarına izin verilmiștir. ${ }^{3}$

Günümüzde bu tatlandırıcıların ürünlerin içerisindeki yaygınlığı ve bunun sonucu olarak da tüketiciler tarafından alımı zamanla artmaktadır. ${ }^{4}$ Yakın zamana kadar, yapay tatlandırıcıların yüksek enerji veya glisemik etki olmaksızın hoş bir tat sunarak sağlıklı beslenmeyi destekleyebileceği savunulmaktaydı. Ancak, hayvan modellerinde yapilan beslenme çalışmalarından ${ }^{5,6}$ elde edilen son veriler, bu görüşün aksine yapay tatlandırıcıların kullanımının enerji dengesini düzensizleştirerek bir takım sağlık problemlerinin oluşmasına katkıda bulunduğunu öne sürmektedir. ${ }^{2} \mathrm{Bu}$ bilgiler doğrultusunda yapay tatlandırılmış içeceklerin düzenli tüketiminin abdominal obezite, insülin direnci ve/veya bozulmuş glukoz toleransı dahil olmak üzere birçok metabolik sendrom risk faktörüyle ilişkilendirilmesi söz konusu olmaktadır.? Yapay tatlandırıcılar içerisinde çeşitli gıda ürünlerinde en yaygın olarak kullanılan tatlandırıcl ise aspartamdır. ${ }^{8}$ Sıklıkla kullanılan aspartamın glukoz intoleransı, karaciğer enzimleri ve oksidatif stres üzerine olumsuz etkilerini gösteren çalışmalar ile birlikte net sonuç alınamayan çalışmalarda bulunmaktadır. ${ }^{5-13}$

Doğal tatlandırıcılardan biri olan ve Paraguay'ın tatlı yaprağı olarak bilinen stevia rebaudiana (bertoni)'nın yaprakları yaklaşık \%4-15 oranında yoğun tatlı bileşikler (şekerden 150-300 kat daha tatlı) olan steviosit içermektedir. ${ }^{14}$ Son zamanlarda sıklıkla kullanılan ve doğal bir 
tatlandırıcı olan stevia ile yapılmış olan deneysel çalıșmalarda ise; stevia'nın insülin duyarlılığını artırdığı, kan glukozunu düşürdüğü, karaciğer enzimleri ve oksidatif stres paremetrelerini azaltığına dair çalışmalar bulunurken, bu parametrelere etkisi olmadığını gösteren çalışmalarda bulunmaktadır. ${ }^{9}, 14-19$

$\mathrm{Bu}$ nedenle günümüzde kullanımı bu kadar sık olan ve metabolik olarak etkileri tam olarak netleştirilemeyen tatlandırıcılar hakkında daha fazla deneysel çalışmaya ihtiyaç duyulmaktadır. Bu derlemede ise doğal ve yapay tatlandırıcıların glukoz intoleransı, karaciğer enzimleri ve oksidatif stres üzerine olan etkilerine yönelik çalışmaların derlenmesi amaçlanmıştır.

\section{Aspartam, kimyasal yapısı ve özellikleri}

Aspartam

(L-aspartylLphenylalanme methyl ester) temelde iki aminoasidin (fenilalanin, aspartik asit) birleşimi ile oluşan sindirilebilir bir dipeptidin metil esteridir. ${ }^{20,21}$ Beyazdır, kokusuzdur ve güçlü tatlı bir tada sahiptir. ${ }^{22}$.

Fenilalanin ve aspartik asidin birleşiminden oluşan aspartam sukroza göre yaklaşık olarak 180 kat daha tatlıdır ve bir gramı dört kkal enerji vermektedir.20,21 Aspartamın FDA tarafindan 1974'de bazı kuru gıdalarda tatlandırıcı ve lezzet arttırıcı olarak kullanılmasına izin verilmiştir. Fakat aspartamı oluşturan temel aminoasitlerin hayvanlar üzerindeki toksik etkilerinden kaynaklanan güvenlik kaygılarına dayanarak bu uygulamaya resmi itirazlar olmuştur ve bunun sonucunda güvenlik sorularını araştırmak için bir Kamu Soruşturma Kurulu kurulmuştur. Bu süreçte aspartam üzerinde seçilen toksikolojik çalışmaların özgünlüğünün kapsamlı bir denetimi yapılırken FDA tarafından aspartam satıșı durdurulmuștur. ${ }^{21}$

FDA 1981 yılında belirli koşullar altında, bir masa üstü tatlandırıcı olarak, sakız, kahvaltı gevrekleri ve belirli gıdalar için kuru bazlarda (içecekler, hazır kahve ve çay, jelatinler, pudingler ve süt ürünleri) aspartam kullanımına tekrar izin vermiștir.
Ayrica aspartam 1983 yllında karbonatlı içecekler ve karbonatlı içecek şurubu bazlarında, 1996 yılında ise genel amaçlı tatlandırıcı olarak FDA tarafından onaylanmıștır. ${ }^{3}$

Avrupa Gida Güvenliği Otoritesi (EFSA) ise 2002 yllından bu yana, aspartamın güvenliğini düzenli olarak gözden geçirmiştir ve bilimsel panellerde bu tatlandırıcı ile ilgili çalışmalar hakkında çeşitli görüşler yayınlamıştır. EFSA önerilerine göre insanlarda aspartamın kabul edilebilir günlük alım miktarı (ADI) 40 $\mathrm{mg} / \mathrm{kg} /$ gün olarak bildirilmektedir. Fakat, fenilketanürü (PKU) hastalarında düşük fenilalanin içeren diyet uygulaması zorunlu olduğu için EFSA'nın vermiş olduğu bu ADI değeri fenilketanüri hastalarında geçerli değildir. ${ }^{23}$

FAO/ WHO Gıda Katkı Maddeleri Uzmanlar Komitesi (JECFA) tarafından da aspartam için ADI değeri aynı EFSA gibi 40 $\mathrm{mg} / \mathrm{kg} /$ gün olarak belirlemiștir. ${ }^{24}$ Tablo 1'de aspartamın genel özelleri ile ilgili bilgiler verilmektedir.

\section{Aspartamın sağlık üzerine etkileri}

Son zamanlarda yapılan deneysel çalışmalarda aspartamın sağlık üzerindeki etkileri araştırılmaktadır. Şu an literatürde aspartamın glukoz intoleransı, karaciğer enzimleri ve oksidatif stres üzerine olumsuz etkilerini gösteren çalışmalar ile birlikte net sonuç alınamayan çalışmalarda bulunmaktadır. ${ }^{5-13}$

Aspartamin deney hayvanları üzerinde olumsuz etkilerinin ele alındığı çalışmalarda; 250, 500 ve $1000 \mathrm{mg} / \mathrm{kg} /$ gün aspartam tüketiminin karaciğer enzimleri olan alanin aminotrensferaz (ALT) ve aspartat aminotrensferaz (AST) seviyelerini anlamlı bir derecede yükselttiği bulunmuştur. 5,6,9 Ayrıca yapılmış olan başka çalışmalarda ise; $40,75,500 \mathrm{mg} / \mathrm{kg} / \mathrm{gün}$ aspartam tüketimi oksidatif stres parametrelerini arttırmıștır ve karaciğer antioksidan kapasitesine zarar vermiştir.8,10,11 Aspartamın sağlık üzerine olumsuz etkisini destekleyecek başka bir çalıșmada ise; 5-7 $\mathrm{mg} / \mathrm{kg} /$ gün aspartam tüketiminin glukoz intoleransına neden 
olduğu ve insülin duyarlılığını bozduğu saptanmiştır. ${ }^{7}$

Yukarıda sonuçları verilen çalışmalardan farklı olarak aspartamın sağlık üzerine etkilerinin net olarak görülmediği ya da olumsuz etkilerinin bulunmadığını gösteren çalışmalarda; 240 $\mathrm{mg} / \mathrm{kg} /$ gün aspartam tüketiminin alanin aminotrensferaz (ALT) değerinde anlamlı bir fark olușturmadığı, günlük $\% 4$ aspartam çözeltisi tüketimi ile birlikte açlık kan glukozunda gruplar arasında anlaml bir farklılık saptanmadığı bulunmuştur.12,25 Ayrıca 40 mg $/ \mathrm{kg} /$ gün aspartam tüketiminin interlökin-2 (IL-2) ve tümör nekrozis faktör alfa (TNF- $\alpha$ ) düzeylerini anlamlı derecede azalttığı bildirilmiştir. ${ }^{13}$

Tablo 1: Aspartamın genel özellikleri

\begin{tabular}{|c|c|}
\hline Tatlandırıcı & Aspartam \\
\hline${ }^{22}$ Kimyasal Ad & N-(L- $\alpha$-Aspartyl)-L-fenilalanine, 1-metil ester \\
\hline${ }^{22}$ Kimyasal Formülü & $\mathrm{C}_{14} \mathrm{H}_{18} \mathrm{~N}_{2} \mathrm{O}_{5}$ \\
\hline 22Molekül Ağırlığı & $294.31 \mathrm{~g} / \mathrm{mol}$ \\
\hline${ }^{22}$ Cas Numarası & {$[22839-47-0]$} \\
\hline${ }^{22}$ Erime Noktası & $246-247^{\circ} \mathrm{C}$ \\
\hline${ }^{19}$ Düzenleyici Durum & $\begin{array}{c}\text { Genellikle gidalarda tatlandırıcı ve lezzet arttırıcı olarak } \\
\text { onaylanmıştır }\end{array}$ \\
\hline $\begin{array}{l}\text { 3Sukroz İle } \\
\text { Karşılaştırıldığında Tatlılık } \\
\text { Yoğunluğu }\end{array}$ & $200 x$ \\
\hline${ }^{32}$ Glisemik İndeks & 0 \\
\hline 32Enerji (kkal/g) & 4 \\
\hline $\begin{array}{l}\text { 23Kabul Edilebilir Günlük } \\
\text { Alım Düzeyi (ADI) (mg/kg) }\end{array}$ & 40 \\
\hline
\end{tabular}

Tablo 2'de yukarıda kısaca bahsedilen deneysel çalışmaların özet şeklindeki açıklamaları yer almaktadır. Bahsedilen çalışmaların sonuçlarına bakıldığında, çalışmalarda kullanılan hayvanların cinsiyetinin- türünün, çalışmaların yapılma sürelerinin, örneklem sayılarının ve verilen tatlandırıcı miktarlarının farklı olmasından dolayı aspartamın glukoz intoleransı, karaciğer enzimleri ve oksidatif stres üzerine etkisi hakkında net bir sonuç ortaya konamamaktadır.

\section{Stevia, kimyasal yapısı ve özellikleri}

Anavatanı Güney Amerika (Paraguay, Brezilya) olan stevia Güney Amerikalı doğa bilimci Antonio Bertoni tarafından 1887 yılında keşfedilmiştir. Çoğu dünya ülkesinde kullanılmakla birlikte özellikle Japonya ve Kore'de otuz yılı aşkın bir süredir gıda katkı maddesi ve tatlandırıcı olarak bireyler tarafından tüketilmektedir. ${ }^{26}$ Beyaz veya açık sarı rengindedir ve hafif bir karakteristik kokuya sahiptir. ${ }^{27}$ 
Kurutulmuş stevia yaprakları sükrozdan 10-15 kat daha tatlı, hatta iyi kaliteli kurutulmuş bir stevia yaprağ sükrozdan 30 kat daha tatlıdır. İşlenen ve toz haline getirilen stevia özütü ise sükrozdan 250-300 kat daha tatlı algılanmaktadır. ${ }^{26,28}$

JECFA, stevia bitkisinden elde edilen tatlllık özelliklerine sahip steviol türevleri ailesi için "steviol glikozitler" terimini kabul etmiştir. Saflaştırılmış steviol glikozitleri (toplam steviol glikozitlerinin $\geq \% 95$ ), stevia rebaudiana bertoni'den türetilen besleyici olmayan tatlandırıcının ortak veya olağan adıdır. Stevianın içeriğine baktığımızda toplam steviol glikozitlerini (temelde rebaudioside A ve stevioside) içerirken, geri kalan kısımda az miktarda rebaudioside B, rebaudioside $C$, rebaudioside $D$, rebaudioside $\mathrm{F}$, dulcoside $\mathrm{A}$, rubusoside ve steviolbioside içermektedir. ${ }^{29}$ JECFA tarafından, steviol glikozitleri için ADI düzeyi ise dört $\mathrm{mg} / \mathrm{kg} /$ gün olarak belirlenmiştir.27 Günümüzde kakao, çikolatalı ürünler, sakız, aromalı içecekler, reçel, jöleler ve marmelatlarda stevia tatlandırıcı olarak kullanılmaktadır. ${ }^{30}$ Tablo 3'te stevianın genel özellikleri verilmiştir.

\section{Stevianın sağlık üzerine etkileri}

Son zamanlarda sıklıkla kullanılan ve doğal bir tatlandırıcı olan stevia ile yapılmış olan deneysel çalışmalarda; stevianın insülin duyarlılığını artırdığı, kan glukozunu düşürdüğü, karaciğer enzimleri ve oksidatif stres paremetrelerini azaltığına dair çalışmalar bulunurken, bu parametrelere etkisi olmadığını gösteren çalışmalarda bulunmaktadır.9, 14-19, 33

Stevianın sağlı üzerine olumlu etkisini gösteren çalışmalarda; 25, 250, 500, $1000 \mathrm{mg} / \mathrm{kg} /$ gün stevia tüketiminin karaciğer enzimlerinden alanin aminotrensferaz (ALT) ve aspartat aminotrensferaz (AST) seviyelerini anlamlı derecede düşürdüğü bulunmuştur.17,33 Ayrıca yapılan başka çalışmalarda; 25, 250, 300,500 ve $1000 \mathrm{mg} / \mathrm{kg} /$ gün stevia tüketiminin kan glukozunu anlamlı derecede düşürdüğü $\quad$ saptanmıştır. ${ }^{14,17,19} \quad \mathrm{Bu}$ çalışmalara ek olarak ise yapılan başka çalışmalarda; \%4 stevia içeren diyet ve 250 ,
$500 \mathrm{mg} / \mathrm{kg} /$ gün steviosit tüketiminin proinflamatuar sitokin olan TNF- $\alpha$, interlökin-1 beta (IL-1 $\beta$ ) ve interlökin-6 (IL6) seviyelerini anlamlı derecede düşürdügü ve karaciğer hasarını önlediği saptanmıştır. ${ }^{18,33}$

Stevianın sağlık üzerine etkisinin bulunamadığı çalışmalarda ise; $250 \mathrm{mg}$ stevia kapsülü ve $500,1000 \mathrm{mg} / \mathrm{kg} / \mathrm{gün}$ stevia rebaudiosit A tüketiminin karaciğer enzimlerinden alanin aminotrensferaz (ALT) ve aspartat aminotrensferaz (AST) seviyelerini anlaml bir derecede değiștirmediği ${ }^{15,16}, 250 \mathrm{mg} / \mathrm{kg} /$ gün stevia kapsülünün kan glukozu ve insülin seviyesini etkilemediği bulunmuştur. ${ }^{15}$

Tablo 4'te yukarıda kısaca bahsedilen deneysel çalışmaların özet şeklindeki açıklamaları yer almaktadır. Bahsedilen çalıșmaların sonuçlarına bakıldığında, çalışmalarda kullanılan hayvanların cinsiyetinin- türünün, çalışmaların yapılma sürelerinin, örneklem sayılarının ve verilen tatlandırıcı miktarlarının farklı olmasından dolayı stevianın glukoz intoleransı, karaciğer enzimleri ve oksidatif stres üzerine etkisi hakkında net bir sonuç ortaya konamamaktadır.

\section{Sonuç ve Öneriler}

Günümüzde düşük enerjili ya da enerji vermeyen tatlandırıcılar şekerlerin yerini büyük ölçüde tutmaya başlamıştır ve sıkça kullanılmaktadırlar. Gıda sektöründe bu tatlandırıcıların bu kadar sık bir biçimde kullanılmaya başlanması akıllara sağlık üzerine etkilerini getirmiştir ve deneysel çalışmalar yapılmaya başlanmıştır. Son yıllarda yapılan çalışmaların sayıca artmaya başlamasına rağmen çalışmalar hala çok yetersizdir ve net sonuçlar ortaya konamamaktadır. Deney hayvanları üzerinde yapılmış olan çalışmalara genel olarak bakıldığında, yapay tatlandırıcı olarak kullanılan aspartamın glukoz intoleransı, karaciğer enzimleri ve oksidatif stres üzerine olumsuz etkisinin olduğu çalışmalar ile birlikte etkisinin olmadığını gösteren çalışmalarda bulunmaktadır. Doğal bir tatlandırıcı olan stevianın ise insülin 
duyarlılığını artırdığı, glukoz intoleransını iyileștirdiği, karaciğer enzimleri ve oksidatif stres paremetrelerini azalttığına dair çalışmalar var olmakla birlikte bu parametrelere etkisinin olmadığını gösteren çalışmalarda bulunmaktadır.

Sonuç olarak deney hayvanları üzerinde yapılan çalışmalarda; çalışma için kullanılan hayvanın türü- cinsiyeti, çalışmanın süresi, verilen tatlandırıcı türümiktarı ve çalışma sonunda değerlendirilecek parametreler farklılık gösterdiği için net bir sonuca varılamamaktadır. $\mathrm{Bu}$ nedenle günümüzde bu kadar sık kullanılan yapay ve doğal tatlandırıcıların sağlık üzerine etkilerini değerlendirmek için daha fazla uzun süreli ve deneysel çalışmaya ihtiyaç duyulmaktadır.

Yazar katkıları: Derleme hazırlanırken; veri toplanması, sonuçların yorumlanması ve derlemenin yazılması aşamalarında yazarlar ortak çalışmış ve eşit derecede emek vermiştir.

Çıkar çatışması: Derleme hazırlanırken; veri toplanması, sonuçların yorumlanması ve derlemenin yazılması aşamalarında yazarlar arasında herhangi bir çıkar çatışması bulunmamaktadır.

Mali destek: $\mathrm{Bu}$ çalışma sırasında, yapılan derleme konusu ile ilgili doğrudan bağlantısı bulunan herhangi bir ilaç firmasından, tıbbi alet, gereç ve malzeme sağlayan ve/veya üreten bir firma veya herhangi bir ticari firmadan, derlemenin değerlendirme sürecinde, derleme ile ilgili verilecek kararı olumsuz etkileyebilecek maddi ve/veya manevi herhangi bir destek alınmamıştır 
Tablo 2: Aspartamın glukoz intoleransı, karaciğer enzimleri ve oksidatif stres üzerine etkisi ile ilgili çalışmalar

\begin{tabular}{|c|c|c|c|c|c|}
\hline Çalışmalar & Aspartam alım miktarı & $\begin{array}{l}\text { Verilen } \\
\text { Aspartam türü }\end{array}$ & $\begin{array}{l}\text { Aspartam } \\
\text { verilme } \\
\text { süresi } \\
\end{array}$ & Denek & Sonuç \\
\hline $\begin{array}{l}\text { 5M. Abhibsh ve } \\
\text { ark; } 2011\end{array}$ & $\begin{array}{l}\text { 1. grup: } 500 \mathrm{mg} / \mathrm{kg} \text { aspartam } \\
\text { 2. grup: } 1000 \mathrm{mg} / \mathrm{kg} \text { aspartam } \\
\text { 3. grup: kontrol grubu (sadece su) } \\
\begin{array}{l}\text { Aspartam su içinde çözündürülerek } \\
\text { veriliyor. }\end{array}\end{array}$ & Aspartam & 180 gün & $\begin{array}{l}18 \text { adet adult male wistar } \\
\text { rat }(150-175 \text { gr }) \\
6 \text { rat x } 3 \text { grup şeklinde } \\
\text { ratlar ayrilmiştır. }\end{array}$ & $\begin{array}{l}\text { Sonuç olarak 1. ve 2. grubun deney } \\
\text { sonunda ALT, AST, GGT ve ALP } \\
\text { seviyeleri yükselmiştir. } \\
\text { 2. grubun ALT, AST, GGT ve ALP } \\
\text { seviyeleri 1. gruba göre } 1.5 \text { kat daha } \\
\text { fazla artış göstermiștir. }\end{array}$ \\
\hline $\begin{array}{l}\text { 10Mourad ve } \\
\text { ark; } 2011\end{array}$ & 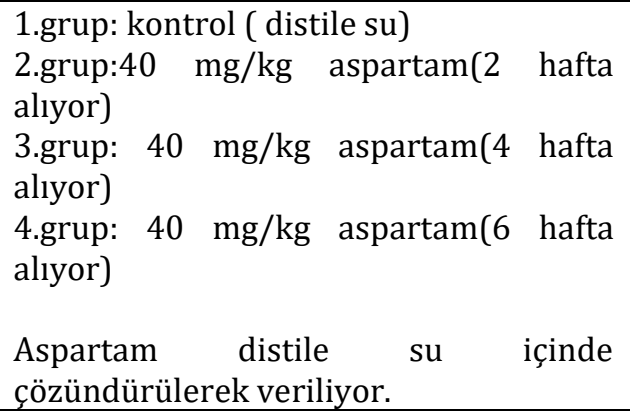 & Aspartam & 42 gün & $\begin{array}{l}\text { Adult male wistar rat } \\
(120-180 \mathrm{gr})\end{array}$ & $\begin{array}{l}\text { Sonuç olarak } 40 \mathrm{mg} / \mathrm{kg} / \text { gün verilen } \\
\begin{array}{lll}\text { aspartamın } & 2 ., 4 . \quad \text { ve } 6 . \text { haftalarda } \\
\text { oksidatif } & \text { stres } & \text { parametrelerini } \\
\text { arttırdığı gözlenmiştir. }\end{array}\end{array}$ \\
\hline $\begin{array}{l}{ }^{8} \text { Ashok ve ark; } \\
2014\end{array}$ & $\begin{array}{l}\text { 1.grup: kontrol } \\
\text { 2. grup: methotrexate (MTX) tedavisi } \\
\text { almiş kontrol grubu } \\
\text { 3. grup: MTX tedavisi almış } 75 \mathrm{mg} / \mathrm{kg} \\
\text { aspartam alan grup }\end{array}$ & Aspartam & 90 gün & $\begin{array}{l}\text { Wistar strain male albino } \\
\text { rats }(200-220 \mathrm{gr}) \\
6 \text { rat x } 3 \text { grup şeklinde } \\
\text { ratlar ayrılmiştır. }\end{array}$ & $\begin{array}{lrrr}\text { Sonuç olarak } & 75 & \mathrm{mg} / \mathrm{kg} / \text { gün } \\
\text { aspartamin } & \text { karaciğer } & \text { antioksidan } \\
\text { kapasitesine } & \text { zarar } & \text { vereceği } \\
\text { gözlenmiştir. } & & \end{array}$ \\
\hline $\begin{array}{l}\text { 7Palmnäs ve } \\
\text { ark; } 2014\end{array}$ & $\begin{array}{l}\text { Hayvanlar ilk başta } 2 \text { hafta boyunca } \\
\text { devam edecek iki diyet grubuna } \\
\text { ayrılıyorlar. } \\
\text { Grup 1: \%12 yağlı yiyecek alan } \\
\text { Grup 2: \%60 yağlı yiyecek alan (yüksek } \\
\text { yağlı grup) } \\
\text { Bu iki hafta sonunda bu gruplarda ikiye } \\
\text { ayrılarak toplam } 4 \text { grup oluşturuluyor. }\end{array}$ & Aspartam & 56 gün & $\begin{array}{l}44 \text { adet erkek sprague } \\
\text { dawley rat }\end{array}$ & $\begin{array}{l}\text { Aspartamın glukoz intoleransına neden } \\
\text { olduğu ve insülin duyarlılığını bozduğu } \\
\text { gözlenmiştir. }\end{array}$ \\
\hline
\end{tabular}




\begin{tabular}{|c|c|c|c|c|c|}
\hline & $\begin{array}{l}\text { Grup 1: \%12 yağlı yiyecek ve su alan } \\
\text { grup } \\
\text { Grup 2: \%60 yağlı yiyecek ve su alan } \\
\text { grup } \\
\text { Grup 3: \%12 yağlı yiyecek ve } \\
\text { 5-7 mg/kg/gün aspartam alan grup } \\
\text { Grup 4: \%60 yağlı yiyecek ve } \\
5-7 \mathrm{mg} / \mathrm{kg} / \text { gün aspartam alan grup }\end{array}$ & & & & \\
\hline $\begin{array}{l}{ }^{6} \text { Alkafafy ve } \\
\text { ark; } 2015\end{array}$ & $\begin{array}{l}\text { 1.grup: } 250 \mathrm{mg} / \mathrm{kg} \text { aspartam } \\
\text { 2.grup: } 1000 \mathrm{mg} / \mathrm{kg} \text { aspartam } \\
\text { 3.grup: } 25 \mathrm{mg} / \mathrm{kg} \text { sakkarin } \\
\text { 4.grup: } 100 \mathrm{mg} / \mathrm{kg} \text { sakkarin }\end{array}$ & $\begin{array}{l}\text {-Aspartam } \\
\text {-Sakkarin } \\
\\
\text { Suda çözülmüş } \\
\text { tatlandırıcılar } \\
\text { oral yolla } \\
\text { verilmiştir. }\end{array}$ & 56 gün & $\begin{array}{l}25 \text { adet } 7 \text { haftalık wistar } \\
\text { albino rat ( } 100 \text { gr) }\end{array}$ & $\begin{array}{l}\text { Sonuç olarak aspartam ve sakkarin alan } \\
\text { grubun ALT ve AST değerleri } \\
\text { yükselmiştir. }\end{array}$ \\
\hline $\begin{array}{l}\text { 110thman ve } \\
\text { Jumah; } 2019\end{array}$ & $\begin{array}{l}\text { 1.grup: kontrol grubu (n:5) } \\
\text { 2. grup: } 500 \mathrm{mg} / \mathrm{kg} \text { aspartam alan grup } \\
\text { Aspartam su içinde çözündürülerek } \\
\text { veriliyor. }\end{array}$ & Aspartam & 7 gün & $\begin{array}{l}20 \text { adet yetișkin diși } \\
\text { albino fare (3-4 aylık, 50- } \\
60 \text { gr) }\end{array}$ & $\begin{array}{l}\text { Sonuç olarak aspartam alan grupta } \\
\text { karaciğer dokusunda yıkım, hücrelerin } \\
\text { yapısında değişim ve hücresel nekroz } \\
\text { gözlenmiştir. }\end{array}$ \\
\hline
\end{tabular}


grupta ise \%50 oranında anlaml derecede azalmıștır.

Ayrica diyabetik ratlarda besin tüketimi aspartam ve stevia alan grupta anlamlı derecede düşmüştür.

\begin{tabular}{|c|c|c|c|c|c|}
\hline $\begin{array}{l}\text { 12Janssens ve } \\
\text { ark; } 2016\end{array}$ & $\begin{array}{l}\text { 1.grup: su } \\
\text { 2.grup: \%13 glukoz içeren çözelti } \\
\text { 3.grup: \%13 fruktoz içeren çözelti } \\
\text { 4.grup: } \% 4 \text { aspartam içeren çözelti }\end{array}$ & $\begin{array}{l}\text {-Glukoz } \\
\text {-Fruktoz } \\
\text {-Aspartam }\end{array}$ & 49 gün & $\begin{array}{l}60 \text { adet yetişkin erkek } \\
\text { wistar rat (3-4 aylık, } \\
350 \pm 2 \text { gr })\end{array}$ & $\begin{array}{l}\text { Açlık kan glukozunda gruplar arasında } \\
\text { anlamlı bir fark gözlenmemiştir. } \\
\text { Plazma ALT seviyeleri fruktoz alan } \\
\text { grupta diğer gruplara kıyasla anlamlı } \\
\text { derecede yüksek çıkmıştır. }\end{array}$ \\
\hline $\begin{array}{l}13 \text { Choudhary ve } \\
\text { Devi; } 2015\end{array}$ & $\begin{array}{l}\text { 1.grup: tuzlu su alan kontrol grubu } \\
\text { 2.grup: folattan fakir diyet alan grup } \\
\text { 3.grup: } 40 \mathrm{mg} / \mathrm{kg} \text { aspartam alan grup } \\
\text { 4.grup: folattan fakir diyet ile birlikte } 40 \\
\text { mg/kg aspartam alan grup } \\
\text { 5.grup: kırmızı kan hücresi aşılanan grup } \\
\text { 6.grup: kırmızı kan hücresi aşılanan ve } \\
\text { folattan fakir diyet alan grup } \\
\text { 7.grup: kırmızı kan hücresi aşılanan ve } \\
40 \mathrm{mg} / \mathrm{kg} \text { aspartam alan grup } \\
\text { 8.grup: kırmızı kan hücresi aşılanan, } \\
\text { folattan fakir diyet alan ve } 40 \mathrm{mg} / \mathrm{kg} \\
\text { aspartam alan grup }\end{array}$ & Aspartam & 90 gün & $\begin{array}{l}48 \text { adet wistar albino rat } \\
(200-220 \mathrm{gr})\end{array}$ & $\begin{array}{l}\text { Sonuç olarak folattan fakir diyetle } \\
\text { birlikte aspartam alan ratlarda, folattan } \\
\text { fakir beslenen ratlara göre IL-2, TNF- } \\
\text { alfa düzeylerinde anlamlı derecede bir } \\
\text { azalma gözlenmiștir. }\end{array}$ \\
\hline
\end{tabular}


Tablo 3: Stevianın genel özellikleri

\begin{tabular}{|c|c|}
\hline Tatlandırıcı & Stevia \\
\hline \multirow[t]{2}{*}{${ }^{31}$ Kimyasal Ad } & $\begin{array}{l}\text { Steviosit:13-[(2-O- } \beta \text {-D-glucopyranosyl- } \beta \text {-D glucopyranosyl)oxy] kaur- } \\
\text { 16-en-18-oic acid, } \beta \text {-D-glucopyranosyl ester }\end{array}$ \\
\hline & $\begin{array}{l}\text { Rebaudiosit A: } 13-[(2-0-\beta-D \text {-glucopyranosyl-3-0- } \beta \text {-Dglucopyranosyl- } \beta \text { - } \\
\text { D glucopyranosyl)oxy]kaur-16-en-18-oic acid, } \beta \text { D-glucopyranosyl ester }\end{array}$ \\
\hline \multirow{2}{*}{$\begin{array}{l}\text { 31Kimyasal } \\
\text { Formülü }\end{array}$} & Steviosit: $\mathrm{C}_{38} \mathrm{H}_{60} \mathrm{O}_{18}$ \\
\hline & Rebaudiosit A: $\mathrm{C}_{44} \mathrm{H}_{70} \mathrm{O}_{23}$ \\
\hline \multirow[t]{2}{*}{ 31Molekül Ağırlığg } & Steviosit: 804.88 \\
\hline & Rebaudiosit A: 967.03 \\
\hline \multirow[t]{2}{*}{${ }^{31}$ Cas Numarası } & Steviosit: $57817-89-7$ \\
\hline & Rebaudiosit A: 58543-16-1 \\
\hline Düzenleyici Durum & Genellikle gıdalarda tatlandırıcı ve enerji düşürücü olarak onaylanmıştır \\
\hline $\begin{array}{l}\text { 31Sukroz İle } \\
\text { Karşılaştırıldığında } \\
\text { Tatlılık Yoğunluğu }\end{array}$ & $200-300 x$ \\
\hline 32Glisemik İndeks & 0 \\
\hline 32Enerji (kkal/g) & 0 \\
\hline $\begin{array}{l}\text { 31Kabul Edilebilir } \\
\text { Günlük Alım } \\
\text { Düzeyi (ADI) } \\
\text { (mg/kg) }\end{array}$ & 4 \\
\hline
\end{tabular}


Tablo 4: Stevianın glukoz intoleransı, karaciğer enzimleri ve oksidatif stres üzerine etkisi ile ilgili çalışmalar

\begin{tabular}{|c|c|c|c|c|c|}
\hline Çalışmalar & Staevia alım miktarı & $\begin{array}{l}\text { Verilen Stevia } \\
\text { türü }\end{array}$ & $\begin{array}{l}\text { Stevia verilme } \\
\text { süresi }\end{array}$ & Denek & Sonuç \\
\hline $\begin{array}{l}{ }^{15} \text { Geuns ve ark; } \\
2006\end{array}$ & 250 mg kapsül & Steviosit Tablet & $\begin{array}{l}3 \text { gün (günde } 3 \\
\text { kez) }\end{array}$ & $\begin{array}{l}10 \text { sağlıklı yetişkin insan } \\
\text { (21-29 yaș arası) }\end{array}$ & $\begin{array}{l}\text { Steviosit alımının kan glukoz, insülin, ALT, } \\
\text { ALP ve GPT değerlerinde anlamlı bir değişiklik } \\
\text { yaratmadığı gözlenmiştir. }\end{array}$ \\
\hline \multirow[t]{3}{*}{$\begin{array}{l}{ }^{16} \text { Nikiforov ve } \\
\text { Eapen; } 2008\end{array}$} & $\begin{array}{l}\text { 1.grup: kontrol grubu(bazal diyet) } \\
\text { 2.grup: } 500 \mathrm{mg} / \mathrm{kg} \text { Rebaudioside A } \\
\text { alan grup }\end{array}$ & \multirow[t]{3}{*}{$\begin{array}{l}\text { Stevia } \\
\text { Rebaudiosit A }\end{array}$} & \multirow[t]{3}{*}{90 gün } & \multirow[t]{3}{*}{$\begin{array}{l}80 \text { adet sprague dawley } \\
\text { rat }\end{array}$} & \multirow[t]{3}{*}{$\begin{array}{l}\text { Rebaudiosit A alımının kan glukoz, insülin } \\
\text { ALT, AST ve ALP değerlerinde anlamlı bir } \\
\text { değişiklik yaratmadığı gözlenmiştir. }\end{array}$} \\
\hline & $\begin{array}{l}\text { 3.grup: } 1000 \mathrm{mg} / \mathrm{kg} \text { Rebaudioside } \\
\text { A alan grup }\end{array}$ & & & & \\
\hline & $\begin{array}{l}\text { 4.grup: } 2000 \mathrm{mg} / \mathrm{kg} \text { Rebaudioside } \\
\text { A alan grup }\end{array}$ & & & & \\
\hline \multirow{5}{*}{$\begin{array}{l}\text { 18 Shivanna ve } \\
\text { ark; } 2013\end{array}$} & Grup 1-2: kontrol grubu & \multirow{5}{*}{$\begin{array}{l}\text { Stevia } \\
\text { Rebaudiana A } \\
\text { Yaprakları }\end{array}$} & \multirow[t]{5}{*}{35 gün } & \multirow{5}{*}{$\begin{array}{l}80 \text { adet streptozosin } \\
(\mathrm{STZ}) \text { kaynakl diyabetik } \\
\text { wistar rat ( } 3 \text { aylık, } 180- \\
200 \mathrm{gr})\end{array}$} & \multirow{5}{*}{$\begin{array}{l}\text { Sonuç olarak stevia rebaudiana A yapraklar } \\
\text { STZ'li diyabetik ratlarda hipoglisemik etkinin } \\
\text { yanı sıra karaciğer ve böbrek hasarını anlaml } \\
\text { derecede azaltmıştır. }\end{array}$} \\
\hline & $\begin{array}{l}\text { Grup 3-4: \%4 stevia içeren diyet ( } \\
96 \text { gr kuru diyette } 4 \text { gr stevia } \\
\text { yaprak tozu) }\end{array}$ & & & & \\
\hline & $\begin{array}{l}\text { Grup 5-6: Eşdeğer miktarda } \\
\text { polifenol ekstresi }\end{array}$ & & & & \\
\hline & $\begin{array}{l}\text { Grup 7-8: } 4 \text { gr stevia yaprağ } \\
\text { tozundan elde edilen eşdeğer } \\
\text { miktarda lif }\end{array}$ & & & & \\
\hline & & & & & \\
\hline \multirow{2}{*}{$\begin{array}{l}{ }^{14} \text { Singh ve ark; } \\
2013\end{array}$} & 1.grup: kontrol grubu & Stevia & \multirow[t]{2}{*}{21 gün } & \multirow{2}{*}{$\begin{array}{l}28 \text { adet sağlıklı swiss } \\
\text { albino fare (4-5 aylık, } 20- \\
30 \text { gr) }\end{array}$} & \multirow{2}{*}{$\begin{array}{l}\text { Alloxan ile diyabetik yapılan farelerde stevia } \\
\text { rebaudiana A yapraklarının verilmesinden }\end{array}$} \\
\hline & $\begin{array}{l}\text { 2.grup: alloxan ile diyabetik } \\
\text { yapilan kontrol rat grubu }\end{array}$ & $\begin{array}{l}\text { Rebaudiana A } \\
\text { Yapraklarının }\end{array}$ & & & \\
\hline
\end{tabular}




\begin{tabular}{|c|c|c|c|c|c|}
\hline & $\begin{array}{l}\text { 3.grup: Standart ilaç tedavisi alan } \\
\text { grup(glibenclamide) }\end{array}$ & $\begin{array}{l}\text { Metanolik } \\
\text { Ekstresi }\end{array}$ & & $\begin{array}{l}7 \text { fare x } 4 \text { grup şeklinde } \\
\text { ratlar ayrilmıştır. }\end{array}$ & $\begin{array}{l}\text { itibaren 21. günün sonunda kan glukozu } \\
\text { anlamlı bir derecede düşmüştür. }\end{array}$ \\
\hline & $\begin{array}{l}\text { 4.grup: } 300 \quad \mathrm{mg} / \mathrm{kg} \text { stevia } \\
\text { rebaudiana alan grup }\end{array}$ & & & $\begin{array}{l}\text { Grup } 3 \text { ve } 4 \text { 'de alloxan ile } \\
\text { diyabetik yapılmıştır. }\end{array}$ & \\
\hline \multirow{5}{*}{$\begin{array}{l}{ }^{19} \text { Akbarzade ve } \\
\text { ark; } 2015\end{array}$} & 1.grup: diabetik kontrol grubu & \multirow{5}{*}{$\begin{array}{l}\text { Stevia } \\
\text { Rebaudiana A } \\
\text { Yaprakları }\end{array}$} & \multirow[t]{5}{*}{30 gün } & \multirow{5}{*}{$\begin{array}{l}40 \text { adet erkek wistar rat } \\
(180-250 \mathrm{~g})\end{array}$} & \multirow{5}{*}{$\begin{array}{l}250 \mathrm{mg} / \mathrm{kg} / \text { gün ve } 500 \mathrm{mg} / \mathrm{kg} / \text { gün stevia } \\
\text { rebaudiana A yaprakları alan grupta diyabetik } \\
\text { kontrol grubuna göre açlık kan glukozu ve } \\
\text { insülin direncinde anlamlı derecede düşme } \\
\text { gözlenmiştir. }\end{array}$} \\
\hline & $\begin{array}{l}\text { 2.grup: diabetik olmayan kontrol } \\
\text { grubu }\end{array}$ & & & & \\
\hline & $\begin{array}{l}\text { 3.grup: } 250 \mathrm{mg} / \mathrm{kg} / \text { gün stevia } \\
\text { alan diyabetik grup }\end{array}$ & & & & \\
\hline & $\begin{array}{l}\text { 4.grup: } 500 \mathrm{mg} / \mathrm{kg} / \text { gün stevia } \\
\text { alan diyabetik grup }\end{array}$ & & & & \\
\hline & $\begin{array}{l}\text { 5.grup: } 750 \mathrm{mg} / \mathrm{kg} / \text { gün stevia } \\
\text { alan diyabetik grup }\end{array}$ & & & & \\
\hline \multirow[t]{6}{*}{$\begin{array}{l}\text { 17Elnaga ve ark; } \\
2015\end{array}$} & $\begin{array}{l}\text { 1.grup: distile su alan negatif } \\
\text { kontrol grubu }\end{array}$ & \multirow[t]{6}{*}{ Stevia } & \multirow[t]{6}{*}{84 gün } & \multirow{6}{*}{$\begin{array}{l}60 \text { adet yetişkin dişi } \\
\text { wistar strain rat }(203 \pm 6 \\
\text { gr) }\end{array}$} & \multirow{6}{*}{$\begin{array}{l}\text { Stevia alımı arttıkça besin alımı azalmıştır. } 25 \\
\text { mg/kg stevia alan grupta besin tüketimi en } \\
\text { fazla iken, } 1000 \mathrm{mg} / \mathrm{kg} \text { stevia alan grupta } \\
\text { besin tüketimi en azdır. Stevia alan gruplarda } \\
\text { anlamlı derecede ağırlık kaybı yaşanmıştır. } \\
\text { Plazma glukoz konsantrasyonu tüm stevia } \\
\text { alan gruplarda azalmıştır. Stevia gruplarında } \\
\text { ALT,AST değerleri anlamlı derecede } \\
\text { düşmüştür. }\end{array}$} \\
\hline & 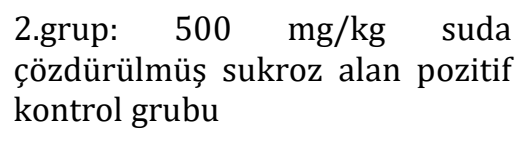 & & & & \\
\hline & 3.grup: $25 \mathrm{mg} / \mathrm{kg}$ stevia alan grup & & & & \\
\hline & $\begin{array}{l}\text { 4.grup: } 250 \mathrm{mg} / \mathrm{kg} \text { stevia alan } \\
\text { grup }\end{array}$ & & & & \\
\hline & $\begin{array}{l}\text { 5.grup: } 500 \mathrm{mg} / \mathrm{kg} \text { stevia alan } \\
\text { grup }\end{array}$ & & & & \\
\hline & $\begin{array}{l}\text { 6.grup: } 1000 \mathrm{mg} / \mathrm{kg} \text { stevia alan } \\
\text { grup }\end{array}$ & & & & \\
\hline \multirow{2}{*}{$\begin{array}{l}{ }^{9} \text { AbdElwahab ve } \\
\text { ark; } 2017\end{array}$} & 1.grup: kontrol grubu sabit diyet & -Stevia & \multirow[t]{2}{*}{42 gün } & \multirow{2}{*}{$\begin{array}{l}60 \text { adet yetişkin erkek } \\
\text { albino rat ( } 2-3 \text { aylık, } 160- \\
200 \text { gr) }\end{array}$} & \multirow{2}{*}{$\begin{array}{l}\text { Stevia alan sağlıklı gruptaki ratlarda ALT, AST, } \\
\text { ALP değerlerinde kontrol grubuna göre } \\
\text { önemli bir fark gözlenmemiştir. Fakat } \\
\text { aspartam alan sağlıklı ratlarda kontrol } \\
\text { grubuna göre ALT, AST, ALP değerlerinde }\end{array}$} \\
\hline & $\begin{array}{l}\text { 2.grup: sağlıklı } 200 \mathrm{mg} / \mathrm{kg} \text { stevia } \\
\text { alan grup }\end{array}$ & -Aspartam & & & \\
\hline
\end{tabular}




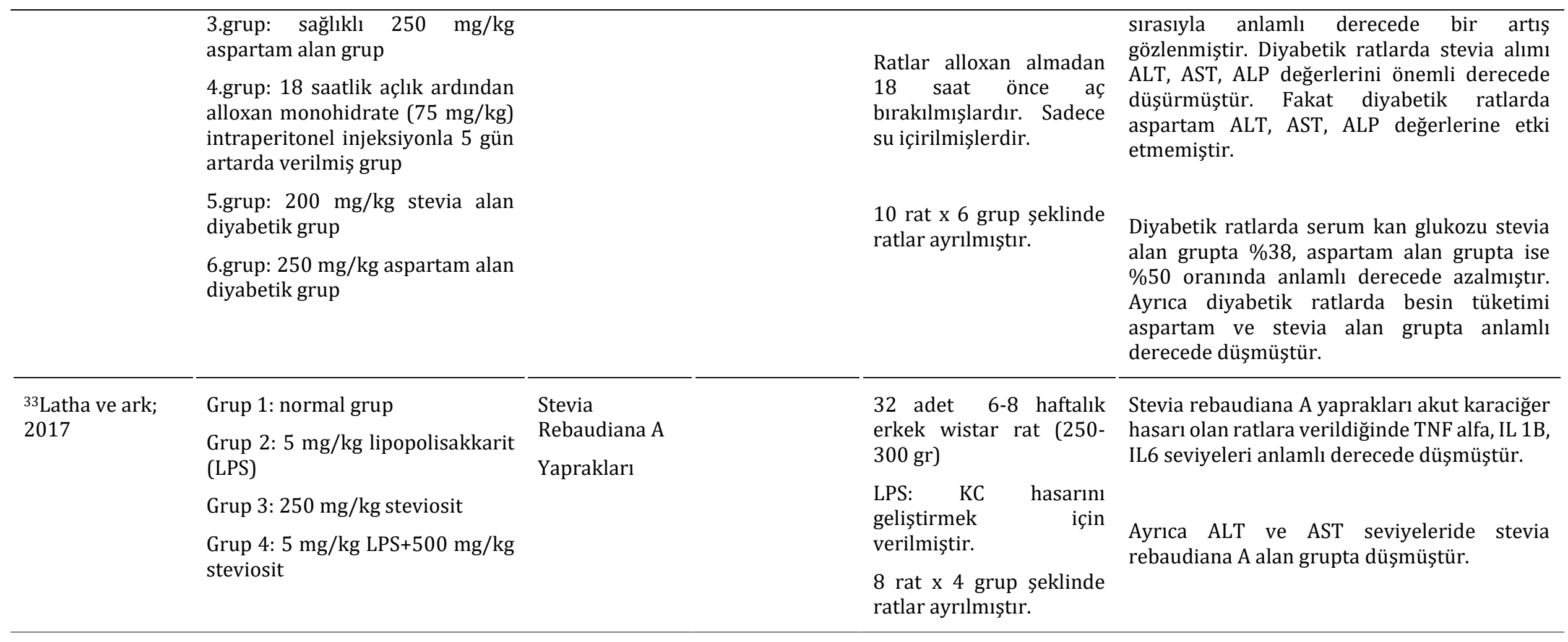




\section{Kaynaklar}

1. Pepino MY. Metabolic effects of nonnutritive sweeteners. Physiology \& Behavior 2015;152:450-455.

2. Pepino MY, \& Bourne C. Nonnutritive sweeteners, energy balance and glucose homeostasis. Current Opinion in Clinical Nutrition and Metabolic Care 2011;14(4):391.

3. High-Intensity sweeteners. Erişim Adresi:https://www.fda.gov/food/foodadditives-petitions/additionalinformation-about-high-intensitysweeteners-permitted-use-food-unitedstates) (Erişim Tarihi:16.07.2019, 13:05)

4. Spencer M, Gupta A, Van Dam L, Shannon C, Menees S, \& Chey WD. Artificial sweeteners: A systematic review and primer for gastroenterologists. Journal of eurogastroenterology and motility 2016;22(2):168.

5. Abhilash M, Paul MS, Varghese MV, \& Nair RH. Effect of long term intake of aspartame on antioxidant defense status in liver. Food Chem Toxicol 2011;49(6):1203-1207.

6. Alkafafy MES, Ibrahim ZS, Ahmed MM, \& El-Shazly SA. Impact of aspartame and saccharin on the rat liver: Biochemical, molecular, and histological approach. International journal of immunopathology and pharmacology 2015;28(2):247-255.

7. Palmnäs MS, Cowan TE, Bomhof MR, Su J, Reimer RA, Vogel HJ, Hittle DS, \& Shearer J. Low-dose aspartame consumption differentially affects gut microbiota-host metabolic interactions in the diet-induced obese rat. PloS one 2014;9(10):1-10.

8. Ashok I, Wankhar D, Sheeladevi R, \& Wankhar W. Long-term effect of aspartame on the liver antioxidant status and histopathology in Wistar albino rats. Biomedicine \& Preventive Nutrition 2014;4(2):299-305.

9. AbdElwahab AH, Yousuf AF, Ramadan BK. \& Elimam H. Comparative Effects of Stevia rebaudiana and Aspartame on hepatorenal function of diabetic rats: Biochemical and Histological Approaches.
Journal of Applied Pharmaceutical Science Vol 2017;7(08):034-042.

10. Mourad M. Effect of aspartame on some oxidative stress parameters in liver and kidney of rats. African Journal of Pharmacy and Pharmacology 2011;5(6):678-862.

11. Otman $\quad \mathrm{S}, \quad \& \quad$ Bin-Jumah $\quad \mathrm{M}$. Histopathological Effect of Aspartame on Liver and Kidney of Mice. International Journal of Pharmacology 2019;15(3):336342.

12. Janssens S, Ciapaite J, Wolters J, van Riel $\mathrm{N}$, Nicolay $\mathrm{K}$, \& Prompers J. An in vivo magnetic resonance spectroscopy study of the effects of caloric and non-caloric sweeteners on liver lipid metabolism in rats. Nutrients 2017;9(5):476.

13. Choudhary A, \& Devi RS. Longer period of oral administration of aspartame on cytokine response in Wistar albino rats. Endocrinología y Nutrición (English Edition) 2015;62(3):114-122.

14. Singh S, Garg V, \& Yadav D. Antihyperglycemic and antioxidative ability of Stevia rebaudiana (Bertoni) leaves in diabetes induced mice. International Journal of Pharmacy and Pharmaceutical Sciences 2013;5(2):297302.

15. Geuns JM, Buyse J, Vankeirsbilck A, \& Temme EH. Metabolism of stevioside by healthy subjects. Experimental biology and medicine 2007;232(1):164-173.

16. Nikiforov AI, \& Eapen AK. A 90-day oral (dietary) toxicity study of rebaudioside A in Sprague-Dawley rats. International journal of toxicology 2008;27(1):65-80.

17. Elnaga NA, Massoud MI, Yousef MI, \& Mohamed HH. Effect of stevia sweetener consumption as non-caloric sweetening on body weight gain and biochemical's parameters in overweight female rats. Annals of Agricultural Sciences 2016;61(1):155-163.

18. Shivanna N, Naika M, Khanum F, \& Kaul VK. Antioxidant, antidiabetic and renal protective properties of Stevia 
rebaudiana. J Diabetes Complications 2013;27(2):103-113.

19. Akbarzadeh S, Eskandari F, Tangestani H, Bagherinejad ST, Bargahi A, Bazzi, P, Daneshi A, Sahrapoor A, O'Connor WJ, \& Rahbar AR. The effect of Stevia rebaudiana on serum omentin and visfatin level in STZ-induced diabetic rats. Journal of dietary supplements 2015;12(1):11- 22.

20. Aspartame suplementary information. Erişim Adresi: https://www.fda.gov/media/89189/do wnload (Erişim Tarihi:17.07.2019, 16:19)

21. Aspartame suplementary information. Erişim Adresi: https://www.fda.gov/media/89219/do wnload (Erişim Tarihi:17.07.2019, 16:19)

22. Aspartame. Erişim Adresi: http://www.fao.org/fileadmin/user_upl oad/jecfa_additives/docs/Monograph1/ additive-046-m1.pdf

(Erişim Tarihi:16.07.2019, 16:07)

23. Aspartame. Erişim Adresi: https://www.efsa.europa.eu/en/topics/t opic/aspartame (Erişim Tarihi: 16.07.2019, 11:09)

24. Aspartame. Erişim Adresi: http://apps.who.int/food-additivescontaminants-jecfa database/chemical.aspx?chemID $=62$ (Erişim Tarihi:16.07.2019, 15:56)

25. Lebda MA, Tohamy HG, \& El-Sayed YS. Long-term soft drink and aspartame intake induces hepatic damage via dysregulation of adipocytokines and alteration of the lipid profile and antioxidant status. Nutrition research 2017;41: 47-55.

26. Çınar A., Stevia ile ilgili genel bilgiler. 1st Balkan Conference of Stevia. 14-16 Şubat 2014 Volos /Yunanistan.

27. Steviol Glycosides from Stevia rebaudiana Bertoni. Erişim Adresi: http://www.fao.org/3/BU297en/bu297 en.pdf (Erişim Tarihi: 17.07.2019, 12:25)

28. Savita S, Sheela K, Sunanda S, Shankar A, \& Ramakrishna P. Steviarebaudiana- A functional component for food industry.
Journal of Human Ecology 2004;15:261264.

29. Purified Steviol Glycosides Primarily Composed of Rebaudioside A and Stevioside. Erişim Adresi: https://www.fda.gov/media/113099/do wnload (Erişim Tarihi:16.07.2019, 16:55)

30. Shannon M, Rehfeld A, Frizzell C, Livingstone C, McGonagle C, Skakkebae, NE, Wielogórska E, \& Connolly L. In vitro bioassay investigations of the endocrine disrupting potential of steviol glycosides and their metabolite steviol, components of the natural sweetener Stevia. Mol Cell Endocrinol 2016;427:65-72.

31. Steviol Glycosides. Erișim Adresi: http://www.fao.org/fileadmin/user_upl oad/jecfa_additives/docs/monograph10 /additive-442-m10.pdf Tarihi:17.07.2019, 12:39)

(Erişim

32. Edwards $\mathrm{CH}$, Rossi M, Corpe CP, Butterworth PJ, \& Ellis PR. The role of sugars and sweeteners in food, diet and health: Alternatives for the future.Trends in food science \& technology 2016;56:158166.

33. Latha S, Chaudhary S, \& Ray R. SHydroalcoholic extract of Stevia rebaudiana bertonleaves and stevioside ameliorates lipopolysaccharide induced acute liver injury in rats. Biomedicine \& Pharmacotherapy 2017;95:1040-1050. 